\title{
Secondary Formation of Aromatic Nitroderivatives of Environmental Concern: Photonitration Processes Triggered by the Photolysis of Nitrate and Nitrite Ions in Aqueous Solution
}

\author{
Giovanna Marussi ${ }^{1}$ and Davide Vione ${ }^{2, *(D)}$ \\ 1 Dipartimento di Scienze Chimiche e Farmaceutiche, Università degli Studi di Trieste, Via Licio Giorgieri 1, \\ 34127 Trieste, Italy; giovanna.marussi@phd.units.it \\ 2 Dipartimento di Chimica, Università degli Studi di Torino, Via Pietro Giuria 5, 10125 Torino, Italy \\ * Correspondence: davide.vione@unito.it; Tel.: +39-011-670-5296
}

check for

updates

Citation: Marussi, G.; Vione, D. Secondary Formation of Aromatic Nitroderivatives of Environmental Concern: Photonitration Processes Triggered by the Photolysis of Nitrate and Nitrite Ions in Aqueous Solution. Molecules 2021, 26, 2550. https:// doi.org/10.3390/molecules26092550

Academic Editors: Rui Fausto and Scott Reed

Received: 16 March 2021

Accepted: 23 April 2021

Published: 27 April 2021

Publisher's Note: MDPI stays neutral with regard to jurisdictional claims in published maps and institutional affiliations.

Copyright: (C) 2021 by the authors. Licensee MDPI, Basel, Switzerland. This article is an open access article distributed under the terms and conditions of the Creative Commons Attribution (CC BY) license (https:// creativecommons.org/licenses/by/ $4.0 /)$.

\begin{abstract}
Aromatic nitroderivatives are compounds of considerable environmental concern, because some of them are phytotoxic (especially the nitrophenols, and particularly 2,4-dinitrophenol), others are mutagenic and potentially carcinogenic (e.g., the nitroderivatives of polycyclic aromatic hydrocarbons, such as 1-nitropyrene), and all of them absorb sunlight as components of the brown carbon. The latter has the potential to affect the climatic feedback of atmospheric aerosols. Most nitroderivatives are secondarily formed in the environment and, among their possible formation processes, photonitration upon irradiation of nitrate or nitrite is an important pathway that has periodically gained considerable attention. However, photonitration triggered by nitrate and nitrite is a very complex process, because the two ionic species under irradiation produce a wide range of nitrating agents (such as ${ }^{\bullet} \mathrm{NO}_{2}, \mathrm{HNO}_{2}, \mathrm{HOONO}$, and $\mathrm{H}_{2} \mathrm{OONO}^{+}$), which are affected by $\mathrm{pH}$ and the presence of organic compounds and, in turn, deeply affect the nitration of aromatic precursors. Moreover, aromatic substrates can highly differ in their reactivity towards the various photogenerated species, thereby providing different behaviours towards photonitration. Despite the high complexity, it is possible to rationalise the different photonitration pathways in a coherent framework. In this context, this review paper has the goal of providing the reader with a guide on what to expect from the photonitration process under different conditions, how to study it, and how to determine which pathway(s) are prevailing in the formation of the observed nitroderivatives.
\end{abstract}

Keywords: nitroaromatic compounds; nitrophenols; atmospheric chemistry; environmental photochemistry; secondary contaminants; photogenerated nitrating agents

\section{Introduction}

The photonitration process is the formation of nitroderivatives from suitable substrates under irradiation conditions [1]. Irradiation is usually essential to the formation of the reactive species (nitrating agents), but in some cases it may also play a key role in activating the substrate to the nitration reaction, which would otherwise not take place in the dark with the same nitrating agent (vide infra for the case of the nitration of nitrophenols) [2].

Starting from earlier works in the early 1980s [3,4], studies on photonitration in aqueous solution have focused on processes that are triggered by the photochemistry of nitrate and nitrite ions. The fact that the reaction takes place in the aqueous phase, the wide environmental occurrence of both nitrate and nitrite, as well as the ability of both ions to absorb environmental UV radiation from sunlight [5], explain why the photonitration reactions have attracted interest, in an attempt to account for the formation of nitroderivatives in surface waters and, most notably, in atmospheric waters and aerosols.

In particular, there has been interest towards photonitration in three successive periods-(i) from the early 1980s to the mid-1990s, when the main goal was to account for the formation of phytotoxic nitrophenols that, together with acid rains, play a role in 
forest decline [6,7]; (ii) the 2000s, when the process attracted attention to account for the occurrence (and secondary formation) of toxic, mutagenic and potentially carcinogenic nitroaromatic compounds in atmospheric aerosols [8,9]; and (iii) the present time, when most interest is accounted for by the fact that the $-\mathrm{NO}_{2}$ group of nitroderivatives enables them to absorb sunlight (visible radiation in addition to the UV, because most nitroderivatives are yellow both as solids and in aqueous solution). As part of the so-called "brown carbon", nitroaromatic compounds play a role in the absorption of sunlight by airborne aerosols and, by so doing, they affect to a potentially significant extent the still-debated and insufficiently defined climate feedback of the aerosols [10-16]. Another reason for the recent interest towards photonitration is the acknowledgement of the important role it may play in photochemical processes for water treatment, which are gaining increasing attention and where the occurrence of nitrate and nitrite under technical UV irradiation might favour the formation of harmful compounds [17-21].

Whatever the reason for the focus on the photonitration reactions, most of the relevant studies had/have to address the issue of the photonitration pathway(s). On the one side, this task is apparently made easy by the fact that both nitrate and nitrite are able to produce the nitrating agent ${ }^{\bullet} \mathrm{NO}_{2}$ (nitrogen dioxide) under irradiation [22]. However, the photonitration process has several features (effect of $\mathrm{pH}$, because photonitration is usually enhanced under acidic conditions, and effect of the addition of scavengers of the hydroxyl radical, ${ }^{\bullet} \mathrm{OH}$, which are very common in the natural environment) that often have to be explained as well. Actually, the attempts to account for the whole features of the photonitration process, based on the role of ${ }^{\bullet} \mathrm{NO}_{2}$ as the sole nitrating agent, and on the $\mathrm{pH}$ effect as only affecting the production of ${ }^{\bullet} \mathrm{NO}_{2}$ by nitrate and nitrite have proven, on the whole, largely unsatisfactory [1]. To make things worse, photonitration appeared to induce the formation of nitroderivatives from substrates that were too electron-poor to react with - $\mathrm{NO}_{2}$ [2]. Indeed, more detailed studies have shown that irradiation of both nitrate and nitrite produces a plethora of potential nitrating agents [23,24], in different amounts (also depending on the conditions, e.g., the $\mathrm{pH}$ of the solution) and with different reactivity, which interact with each substrate to finally produce the observed effects. Therefore, the photonitration process is not amenable to a simple explanation, based on the role of a single nitrating agent.

Unfortunately, essential information about the photonitration pathway(s) has been fragmented in several different publications, and there is currently not a single paper where all the mechanistic findings are summarised and compared. This review paper is intended to fill this gap, also in view of the recent interest towards the photochemical formation of nitroderivatives as brown-carbon components, and as potential contaminants of treated water and wastewater. Therefore, researchers working in the photonitration field could find here a reference and a guide through an environmentally interesting but, at the same time, very tricky process. This review paper deals with the photonitration of aromatic compounds, which has been the main research focus so far. However, it is important to point out that the formation of nitro- and nitrosoderivatives under irradiation has also been observed in the presence of aliphatic precursors such as primary amines [25], which have the potential to yield toxic and carcinogenic compounds.

The present review paper starts by describing the processes that follow the irradiation of both nitrate and nitrite ions, which on the one side are long known [22], but where some key details have been fully elucidated only more recently, to account for some features of the photonitration process $[23,26]$. It follows an account of the photonitration of phenol, a substrate that can react with virtually all photogenerated nitrating agents-the elucidation of phenol photonitration pathways was actually the starting point to really understand the nature of the process [27]. Peculiar case studies are then presented, with substrates that help highlight particular reactions, and for which the photonitration mechanism has been convincingly elucidated within a coherent framework. Finally, considering that there is quite convincing evidence for aromatic photonitration to occur in natural surface waters [5,28-30], at least under particular conditions [31], the details of such a process are shown as well. Because natural waters are much more complex than laboratory model 
systems, allowance is here made for the likely interaction between different surface-water components. Conclusions follow in the end.

\section{Aromatic Photonitration in Aqueous Solution}

\subsection{Nitrate $\left(\mathrm{NO}_{3}{ }^{-}\right)$Photolysis}

Nitrate absorbs sunlight up to approximately $340 \mathrm{~nm}$. It has a weak absorption maximum at $302 \mathrm{~nm}\left(\varepsilon_{\max }=7.2 \mathrm{~L} \mathrm{~mol}^{-1} \mathrm{~cm}^{-1}\right)$ and, because the irradiance of sunlight increases with increasing wavelength in the UV region, one gets that sunlight absorption by nitrate is most effective at around $315-320 \mathrm{~nm}$. Radiation absorption breaks the $\mathrm{NO}_{3}{ }^{-}$ ion into two fragments, namely $\mathrm{O}^{\bullet-}$ and ${ }^{\bullet} \mathrm{NO}_{2}$, where $\mathrm{O}^{\bullet-}$ is the conjugate base of the hydroxyl radical, $\bullet$ OH $[22,32]$ :

$$
\mathrm{NO}_{3}{ }^{-}+\mathrm{h} v \rightarrow\left[{ }^{\bullet} \mathrm{NO}_{2}+\mathrm{O}^{\bullet-}\right]_{\text {cage }} \quad[\Phi=0.01]
$$

where $\Phi$ is the quantum yield of nitrate photolysis (ratio between photolysed molecules and absorbed photons). The two photogenerated fragments are initially located inside a cage of water molecules, where three alternative processes can take place [23,33]:

1. Diffusion of ${ }^{\bullet} \mathrm{NO}_{2}+\mathrm{O}^{\bullet-}$ out of the solvent cage and into the solution bulk, where $\mathrm{O}^{\bullet-}$ undergoes prompt protonation to ${ }^{\bullet} \mathrm{OH}$ if $\mathrm{pH}<12$;

2. Geminate recombination of the two fragments back to the original $\mathrm{NO}_{3}{ }^{-}$; and

3. Recombination of the fragments to form peroxynitrite, $\mathrm{ONOO}^{-}$, which is an isomer of nitrate (this latter process takes the form of nitrate photoisomerisation). Peroxynitrite is the conjugate base of the weak acid $\mathrm{HOONO}\left(\mathrm{pK}_{\mathrm{a}}=7\right)$, peroxynitrous acid. HOONO is an unstable species that can either give back nitrate or decompose into ${ }^{\bullet} \mathrm{OH}+{ }^{\bullet} \mathrm{NO}_{2}$. In contrast, $\mathrm{OONO}^{-}$mainly reacts with dissolved $\mathrm{CO}_{2}$ [24].

$$
\begin{gathered}
{\left[{ }^{\bullet} \mathrm{NO}_{2}+\mathrm{O}^{\bullet-}\right]_{\text {cage }} \rightarrow{ }^{\bullet} \mathrm{NO}_{2}+\mathrm{O}^{\bullet-}} \\
\mathrm{O}^{\bullet-}+\mathrm{H}^{+} \leftrightarrows \\
{ }^{\bullet} \mathrm{OH} \quad\left[\mathrm{pK}_{\mathrm{a}}(\bullet \mathrm{OH})=11.9\right] \\
{\left[\mathrm{NO}_{2}+\mathrm{O}^{\bullet-}\right]_{\text {cage }} \rightarrow \mathrm{NO}_{3}^{-}} \\
{\left[\mathrm{NO}_{2}+\mathrm{O}^{\bullet-}\right]_{\text {cage }} \rightarrow \mathrm{OONO}^{-}} \\
\mathrm{OONO}^{-}+\mathrm{CO}_{2} \rightarrow \mathrm{ONOOCO}_{2}^{-} \\
\mathrm{OONO}^{-}+\mathrm{H}^{+} \leftrightarrows \mathrm{HOONO}^{-} \\
\mathrm{HOONO} \rightarrow \mathrm{NO}_{3}^{-} \\
\mathrm{HOONO} \rightarrow{ }^{\bullet} \mathrm{OH}+{ }^{\bullet} \mathrm{NO}_{2}
\end{gathered}
$$

The processes triggered by nitrate photolysis are summarised in the following Scheme 1 .

Among the species formed by nitrate photolysis, ${ }^{\bullet} \mathrm{NO}_{2}, \mathrm{HOONO}$ and $\mathrm{H}_{2} \mathrm{OONO}{ }^{+}$(the conjugate acid of $\mathrm{HOONO}$; note that $\mathrm{H}_{2} \mathrm{OONO}^{+}$has $\mathrm{pK}_{\mathrm{a}}<0$ ) are all nitrating agents [2,34]. Nitrogen dioxide is unstable in aqueous solution, where it undergoes dimerisation to $\mathrm{N}_{2} \mathrm{O}_{4}$ and hydrolysis $[22,35,36]$ :

$$
\begin{gathered}
2 \cdot \mathrm{NO}_{2} \leftrightarrows \mathrm{N}_{2} \mathrm{O}_{4}\left[k=4.5 \times 10^{8} \mathrm{~L} \mathrm{~mol}^{-1} \mathrm{~s}^{-1} ; k_{-}=6.9 \times 10^{3} \mathrm{~s}^{-1}\right] \\
\mathrm{N}_{2} \mathrm{O}_{4}+\mathrm{H}_{2} \mathrm{O} \rightarrow \mathrm{HNO}_{2}+\mathrm{NO}_{3}^{-}+\mathrm{H}^{+}\left[\mathrm{k}=1.0 \times 10^{3} \mathrm{~s}^{-1}\right] \\
\mathrm{HNO}_{2} \leftrightarrows \mathrm{H}^{+}+\mathrm{NO}_{2}{ }^{-}\left[\mathrm{pK}_{\mathrm{a}}=3.3\right]
\end{gathered}
$$

Nitrous acid, $\mathrm{HNO}_{2}$, is another nitrating agent that is active towards electron-rich compounds such as phenols [14].

\subsection{Nitrite $\left(\mathrm{NO}_{2}^{-}\right)$Photolysis}

The nitrite anion has two main absorption bands in the environmental UV region. The lower-wavelength band appears as a $270-280 \mathrm{~nm}$ shoulder in the nitrite absorption 
spectrum, and it extends into the UVB region where it overlaps with the higher-wavelength band. The latter produces a clear absorption maximum at around $365 \mathrm{~nm}$. Radiation absorption by nitrite in the environmental UV region (both UVB and UVA) causes photolysis with generation of ${ }^{\bullet} \mathrm{NO}+\mathrm{O}^{\bullet-}$ as the primary process, and of ${ }^{\bullet} \mathrm{NO}_{2}+\mathrm{e}^{-}$aq as a secondary one [22]:

$$
\begin{gathered}
\mathrm{NO}_{2}{ }^{-}+\mathrm{h} v \rightarrow{ }^{\bullet} \mathrm{NO}+\mathrm{O}^{\bullet-}\left[\Phi^{\prime}=0.025-0.065\right] \\
\mathrm{O}^{\bullet-}+\mathrm{H}^{+} \leftrightarrows{ }^{\bullet} \mathrm{OH} \\
\mathrm{NO}_{2}{ }^{-}+\mathrm{h} v \rightarrow{ }^{\bullet} \mathrm{NO}_{2}+\mathrm{e}^{-} \text {aq }\left[\Phi^{\prime \prime} \sim 0.001\right]
\end{gathered}
$$

The quantum yield $\Phi^{\prime}$ of Reaction (13) depends on the nitrite band that is involved in radiation absorption. Indeed, the short-wavelength band has a quantum yield $\Phi^{\prime}=0.065$, while the long-wavelength band has $\Phi^{\prime}=0.025$. In the environmental UV range, absorption by $\mathrm{NO}_{2}{ }^{-}$in the short-wavelength band decreases as the wavelength increases, while absorption in the long-wavelength band does the reverse, at least up to the maximum at $365 \mathrm{~nm}$. As a consequence, the quantum yield $\Phi^{\prime}$ has a value of 0.065 at 280-290 nm, which decreases down to 0.025 in the UVA region [22]. Interestingly, nitrite can be oxidised by the same ${ }^{\bullet} \mathrm{OH}$ radicals it generates under irradiation, with subsequent production of ${ }^{\bullet} \mathrm{NO}_{2}$ :

$$
\mathrm{NO}_{2}{ }^{-}+\bullet \cdot \mathrm{OH} \rightarrow{ }^{\bullet} \mathrm{NO}_{2}+\mathrm{OH}^{-}\left[k=1.0 \times 10^{10} \mathrm{~L} \mathrm{~mol}^{-1} \mathrm{~s}^{-1}\right]
$$

The above reaction accounts for most of the formation of the nitrating agent ${ }^{\bullet} \mathrm{NO}_{2}$ in the presence of irradiated nitrite $[27,37]$. Interestingly, the occurrence of $\bullet$ NO and $\bullet \mathrm{NO}_{2}$ in the same system triggers an efficient process of nitrite regeneration:

$$
\begin{aligned}
& \bullet \mathrm{NO}+{ }^{\bullet} \mathrm{NO}_{2} \leftrightarrows \mathrm{N}_{2} \mathrm{O}_{3}\left[k=1.1 \times 10^{9} \mathrm{~L} \mathrm{~mol}^{-1} \mathrm{~s}^{-1}\right] \\
& \mathrm{N}_{2} \mathrm{O}_{3}+\mathrm{H}_{2} \mathrm{O} \rightarrow 2 \mathrm{NO}_{2}{ }^{-}+2 \mathrm{H}^{+}\left[k=5.3 \times 10^{2} \mathrm{~s}^{-1}\right]
\end{aligned}
$$

Therefore, although $\mathrm{NO}_{2}{ }^{-}$is oxidised by ${ }^{\bullet} \mathrm{OH}$, this reaction plays a key role in the regeneration of $\mathrm{NO}_{2}{ }^{-}$rather than in its degradation. As a consequence, the disappearance of $\mathrm{NO}_{2}{ }^{-}$is considerably faster in the presence of ${ }^{\bullet} \mathrm{OH}$ scavengers that inhibit Reaction (16) and, therefore, inhibit nitrite regeneration as well [38]. The processes described above are summarised in Scheme 2.

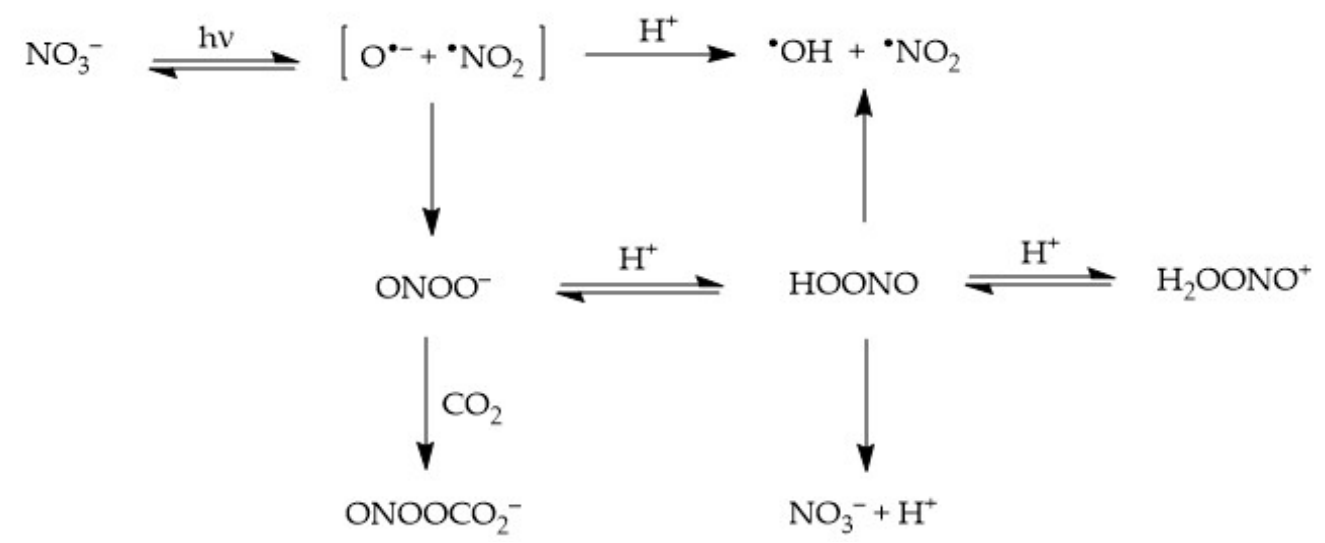

Scheme 1. Primary photoprocesses and early subsequent reactions triggered by the photolysis of $\mathrm{NO}_{3}{ }^{-}$.

Nitrite is a weak base that forms nitrous acid in acidic solution $\left(\mathrm{HNO}_{2}\right.$, also indicated as $\mathrm{HONO}$ in the field of atmospheric chemistry). $\mathrm{HNO}_{2}$ is an unstable weak acid with $\mathrm{pK}_{\mathrm{a}}=3-3.5$; it absorbs radiation in about the same wavelength range as nitrite, and with roughly comparable absorption coefficients $\left(\lambda_{\max }=371 \mathrm{~nm}, \varepsilon_{\max }=51.9 \mathrm{~L} \mathrm{~mol}^{-1} \mathrm{~cm}^{-1}\right)$. 
The photolysis of nitrous acid yields ${ }^{\bullet} \mathrm{NO},{ }^{\bullet} \mathrm{OH}$ and ${ }^{\bullet} \mathrm{NO}_{2}$ in a similar way as nitrite photolysis [22,39]:

$$
\begin{gathered}
\mathrm{HNO}_{2}+\mathrm{hv} \rightarrow{ }^{\bullet} \mathrm{NO}+{ }^{\bullet} \mathrm{OH}[\Phi=0.35] \\
\mathrm{HNO}_{2}+{ }^{\bullet} \mathrm{OH} \rightarrow{ }^{\bullet} \mathrm{NO}_{2}+\mathrm{H}_{2} \mathrm{O}\left[k=2.6 \times 10^{9} \mathrm{~L} \mathrm{~mol}^{-1} \mathrm{~s}^{-1}\right]
\end{gathered}
$$

However, the direct photolysis quantum yield of $\mathrm{HONO}(\Phi=0.35)$ is much higher than that of nitrite $(\Phi=0.025-0.065)$, thus the photochemical reactivity of nitrite-containing solutions increases as the $\mathrm{pH}$ decreases. Interestingly, the UVA absorption spectrum of HONO shows a vibrational fine structure that is lacking in the nitrite spectrum. Moreover, HONO absorption is not extended into the visible region, while concentrated nitrite solutions are pale yellow.

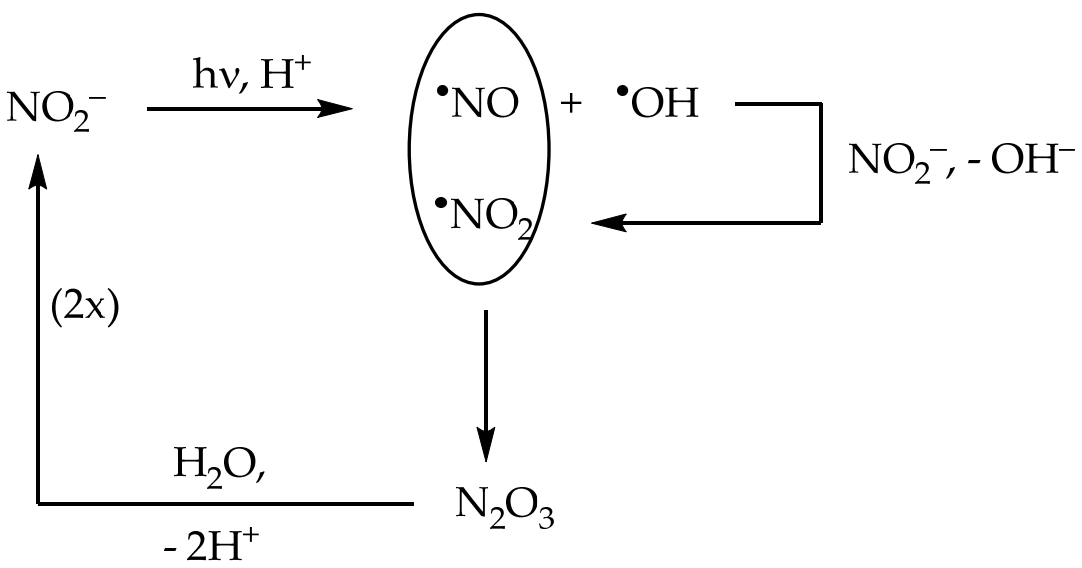

Scheme 2. Primary photoprocesses and early subsequent reactions triggered by the photolysis of $\mathrm{NO}_{2}{ }^{-}$.

The absorption spectra of nitrate, nitrite and nitrous acid are reported in Figure 1, where they are compared with summertime and wintertime spectra of sunlight under mid-latitude conditions.

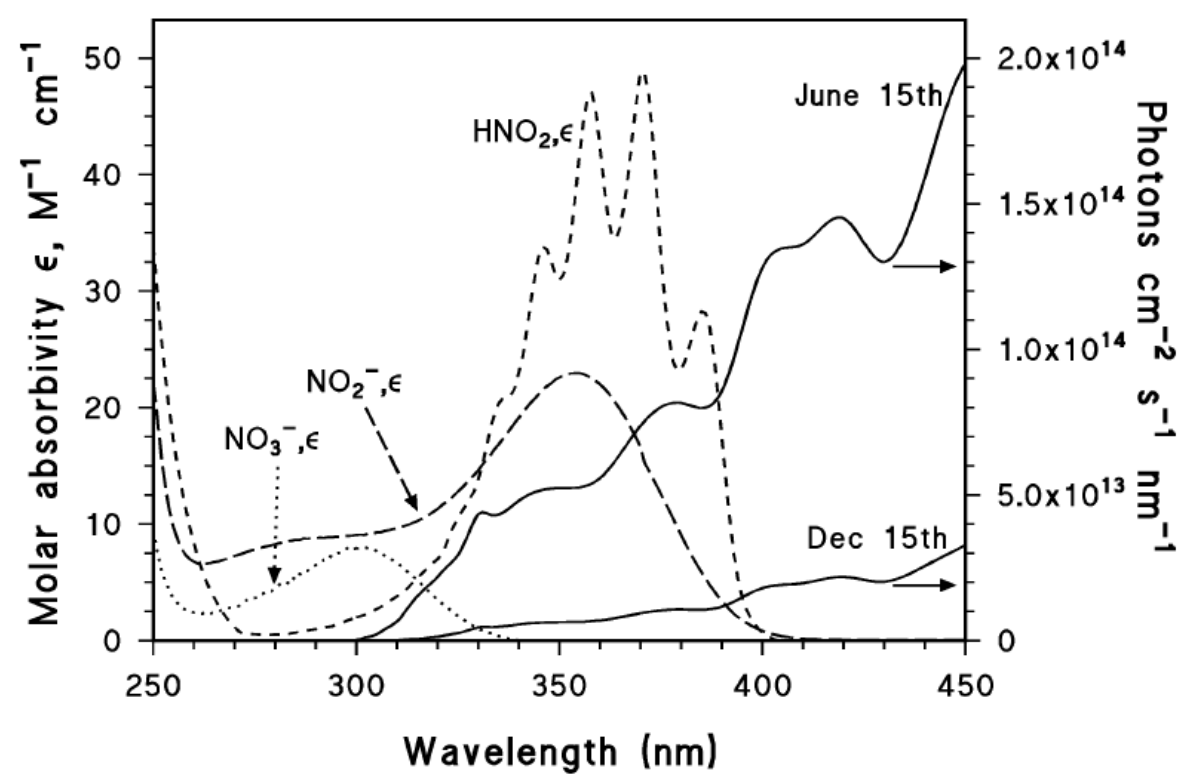

Figure 1. Left y axis. Molar absorption coefficients of $\mathrm{NO}_{3}{ }^{-}, \mathrm{NO}_{2}{ }^{-}$and $\mathrm{HNO}_{2}$. Right y axis. Spectral photon flux density of sunlight in mid-latitude conditions, during summertime and wintertime (northern hemisphere). Vione, unpublished data. 


\subsection{A Brief Overview of the Different Photogenerated Nitrating Agents}

As shown in the previous sections, the irradiation of nitrate and nitrite yields different nitrating agents such as $\mathrm{NO}_{2}, \mathrm{HNO}_{2}$, and $\mathrm{HOONO}$ (which can be partially protonated to $\mathrm{H}_{2} \mathrm{OONO}^{+}$in strongly acidic conditions). Electron-rich aromatics will mostly be nitrated by ${ }^{\bullet} \mathrm{NO}_{2}$ or $\mathrm{HNO}_{2}$ that are formed or occur in a higher amount [6,26], while $\mathrm{HOONO} / \mathrm{H}_{2} \mathrm{OONO}^{+}$(however powerful their potential towards aromatic nitration may be [40-42]) are produced with low quantum yield by nitrate irradiation. Therefore, the reactivity of $\mathrm{HOONO} / \mathrm{H}_{2} \mathrm{OONO}^{+}$will only be highlighted in the presence of deactivated aromatic compounds that do not react with ${ }^{\bullet} \mathrm{NO}_{2} / \mathrm{HNO}_{2}$ [2].

The role of the different nitrating agents in the photonitration of a given compound can be highlighted when taking into account the peculiar $\mathrm{pH}$ trends that characterise at least some of them. Indeed, $\mathrm{H}_{2} \mathrm{OONO}^{+}$has $\mathrm{pK}_{\mathrm{a}}<0$, $\mathrm{HOONO}$ has $\mathrm{pK}_{\mathrm{a}} \sim 7$, while $\mathrm{HNO}_{2}$ has $\mathrm{pK}_{\mathrm{a}} \sim 3.5[22,40]$. Moreover, $\mathrm{HNO}_{2}$ can also be involved in a nitrosation/oxidation process that gives a maximum in nitroaromatic formation at $\mathrm{pH} 2-3$ [43]. Figure 2 shows the $\mathrm{pH}$ trends that characterise the occurrence and/or reactivity of the different nitrating agents, and that may be reflected in the rates of nitroaromatic formation as a function of $\mathrm{pH}$. Indeed, a study of the $\mathrm{pH}$ trend should be a key step when trying to understand the aromatic photonitration pathways (vide infra).

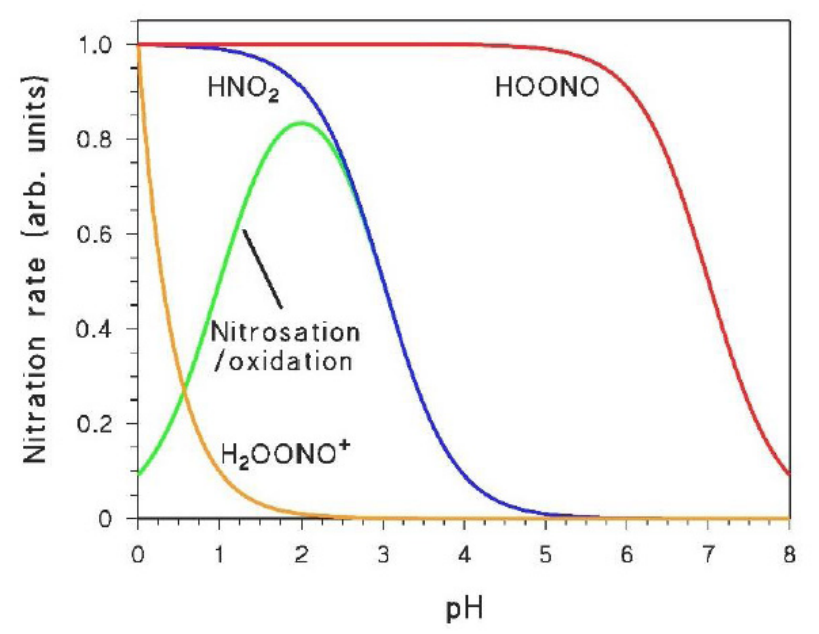

Figure 2. Trends, as a function of $\mathrm{pH}$, of the occurrence of nitrating agents (or of nitration processes) that are produced (or can be triggered) under irradiation.

The following sections provide a number of case studies concerning the photonitration of several aromatic compounds, highlighting the main nitrating agents that are involved in the process and, when available, describing the underlying nitration mechanism(s).

\subsection{Phenol Photonitration Pathways}

Formation of the ortho and para nitrophenol isomers (2-nitrophenol and 4-nitrophenol, hereinafter respectively $2 \mathrm{NP}$ and $4 \mathrm{NP}$ ) from phenol has been observed upon irradiation of both nitrate and nitrite [1,6]. In neutral solution, in both cases, the photonitration process has been shown to involve a reaction between phenol and ${ }^{\prime} \mathrm{NO}_{2}$, with the likely involvement of the phenoxyl radical as a reaction intermediate (Scheme 3). This most likely reaction pathway has been suggested by quantum chemistry calculations as well [27].

It is interesting to observe that the formation of 2- and 4-nitrophenol is peculiar for the nitration of phenol, which does not yield the meta isomer (3-nitrophenol). In contrast, formation of the latter compound (together with the other two nitrophenol isomers) has been observed upon hydroxylation of nitrobenzene [44].

The photonitration of phenol upon irradiation of nitrate has three main features, the explanation of which has been key to understanding the reaction pathway(s) involved- 
(i) it is favoured in the absence of oxygen; (ii) it is enhanced upon addition of ${ }^{\bullet} \mathrm{OH}$ scavengers such as 2-propanol; (iii) it is enhanced under acidic $\mathrm{pH}$ conditions [1,6].<smiles>Oc1ccccc1</smiles><smiles>CC(C)[N+](=O)[O-]</smiles><smiles>[O-]c1ccccc1</smiles><smiles>O=[N+]([O-])c1ccccc1O</smiles>

Scheme 3. Nitration pathway of phenol by ${ }^{\bullet} \mathrm{NO}_{2}$. The formation of $2 \mathrm{NP}$ and $4 \mathrm{NP}$ follow similar pathways.

In the presence of dissolved oxygen, different reaction pathways yield the superoxide radical anion $\mathrm{O}_{2}{ }^{\bullet-}$ (indeed, $\mathrm{HO}_{2}{ }^{\bullet} / \mathrm{O}_{2}{ }^{\bullet-}$ are typical products of the reactions between organics and ${ }^{\bullet} \mathrm{OH}$ [45]). Superoxide is able to reduce phenoxyl back to phenol [46] (Scheme 4), thereby inhibiting the photonitration process. Therefore, nitrophenol formation is enhanced in the absence of oxygen.

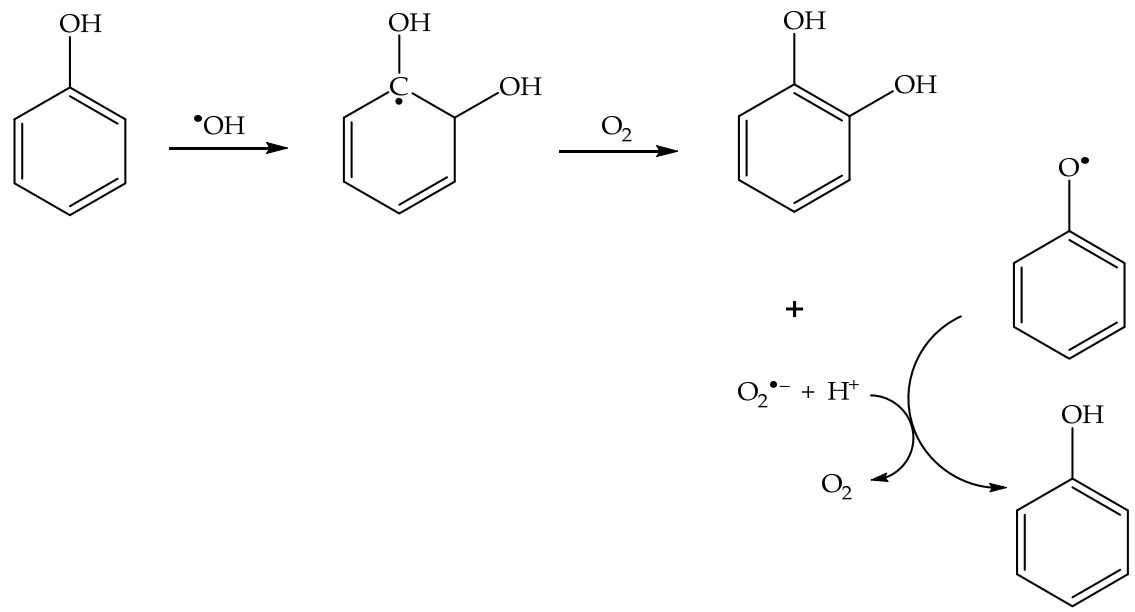

Scheme 4. Photoinduced formation of superoxide, and its role in phenoxyl reduction to phenol.

The addition of ${ }^{\bullet} \mathrm{OH}$ scavengers at high enough concentration leads to the consumption of not only bulk ${ }^{\bullet} \mathrm{OH}$, but also of cage $\mathrm{O}^{\bullet-}[23,47]$. By inhibiting cage recombination between $\mathrm{O}^{\bullet-}$ and $\bullet \mathrm{NO}_{2}$, scavengers such as 2-propanol (PrOH) enhance the photochemical production of ${ }^{\bullet} \mathrm{NO}_{2}$ (Scheme 5), thereby enhancing as well the photonitration process [23].

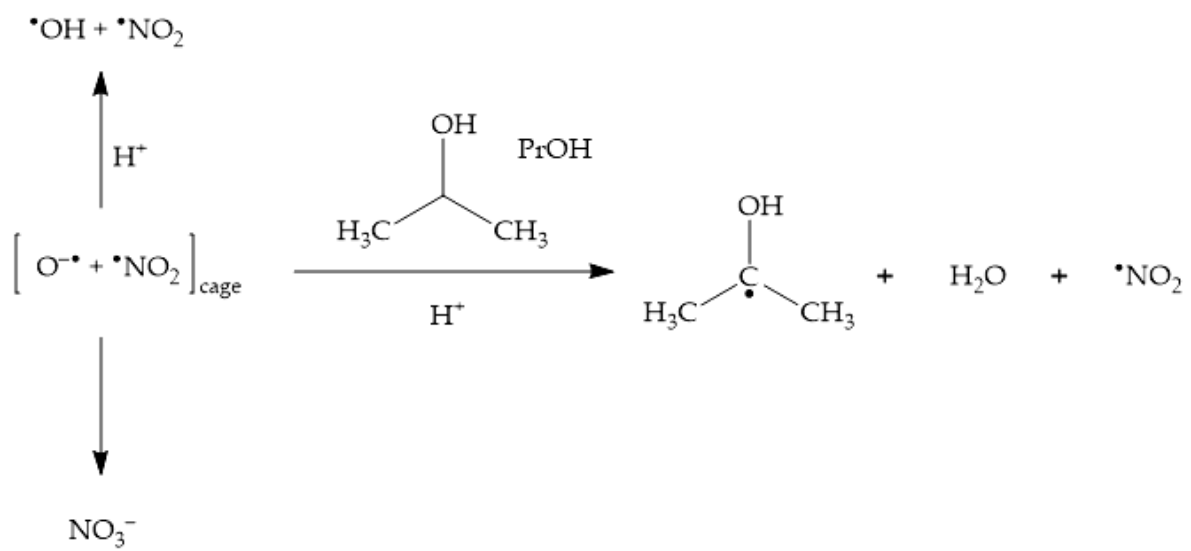

Scheme 5. Enhancement of ${ }^{\bullet} \mathrm{NO}_{2}$ formation upon nitrate photolysis by the ${ }^{\bullet} \mathrm{OH}$ scavenger 2propanol $(\mathrm{PrOH})$. 
Interestingly, the enhancement of photonitration by ${ }^{\bullet} \mathrm{OH}$ scavengers allows for the exclusion of a photonitration pathway involving ${ }^{\bullet} \mathrm{OH}+{ }^{\bullet} \mathrm{NO}_{2}$ (Scheme 6), proposed in analogy with some gas-phase nitration processes [48,49]:<smiles>O=[N+]([O-])c1ccc(O)cc1C(O)C1C=CC(O)=CC1[N+](=O)[O-]</smiles>

Scheme 6. Phenol nitration by ${ }^{\bullet} \mathrm{OH}+{ }^{\bullet} \mathrm{NO}_{2}$, which is not operational as photonitration pathway.

Finally, under acidic $\mathrm{pH}$ conditions, one has the production of $\mathrm{HNO}_{2}$ upon ${ }^{\bullet} \mathrm{NO}_{2}$ hydrolysis (reactions 10,11), and $\mathrm{HNO}_{2}$ is another effective nitrating agent for phenols [50]. In particular, the nitration of phenol by $\mathrm{HNO}_{2}$ follows two reaction pathways-a direct one, where $\mathrm{HNO}_{2}$ is initially involved in the oxidation of phenol to phenoxyl, and a nitrosation/oxidation process (Scheme 7). Nitration by $\mathrm{HNO}_{2}$ alone is enabled by the decomposition of $\mathrm{HNO}_{2}$ into $\bullet \mathrm{NO}+{ }^{\bullet} \mathrm{NO}_{2}[43,51]$.

$$
2 \mathrm{HNO}_{2} \rightarrow \bullet \mathrm{NO}+{ }^{\bullet} \mathrm{NO}_{2}+\mathrm{H}_{2} \mathrm{O}
$$<smiles></smiles>

Scheme 7. Phenol nitration pathways by $\mathrm{HNO}_{2}$ : (a) direct nitration; (b) nitrosation/oxidation. Note that similar processes would produce $4 \mathrm{NP}$ in addition to $2 \mathrm{NP}$.

The involvement of $\mathrm{HNO}_{2}$ in phenol photonitration with nitrate in acidic solution is supported by the fact that the initial formation rates of $2 \mathrm{NP}$ and $4 \mathrm{NP}$ both show an inflection point at $\mathrm{pH} \sim 3.5$, which is fully compatible with the $\mathrm{pK}_{\mathrm{a}}$ of $\mathrm{HNO}_{2}$ [52].

In the presence of irradiated nitrite, the formation rate of nitrophenols is considerably higher compared to the case of nitrate. The photonitration of nitrophenols by nitrite has the following features-(i) it is inhibited by the addition of ${ }^{\bullet} \mathrm{OH}$ scavengers, and (ii) it is enhanced at acidic $\mathrm{pH}$ [6]. The addition of ${ }^{\bullet} \mathrm{OH}$ scavengers such as $\mathrm{PrOH}$ inhibits the oxidation of $\mathrm{NO}_{2}{ }^{-}$to ${ }^{\bullet} \mathrm{NO}_{2}$ by ${ }^{\bullet} \mathrm{OH}$ (Scheme 8), thereby inhibiting phenol nitration as well $[6,52]$.

The $\mathrm{pH}$ effect in the presence of nitrite shows the same inflection point at $\mathrm{pH} \sim 3.5$ already seen with nitrate, which strongly suggests the involvement of $\mathrm{HNO}_{2}$. However, in acidified nitrite solutions both the thermal process (direct reaction between phenol and $\mathrm{HNO}_{2}$, or nitrosation/oxidation) and the photoinduced one (higher photoreactivity of $\mathrm{HNO}_{2}$ compared to $\mathrm{NO}_{2}{ }^{-}$to yield ${ }^{\bullet} \mathrm{NO}_{2}$ ) are operational at the same time. Therefore, with $\mathrm{NO}_{2}{ }^{-}$at $\mathrm{pH}<5$ it is very difficult to understand which fraction of nitrophenol formation is thermal and which is photoinduced, although experimental evidence points at a prevalence of the thermal process [53]. 


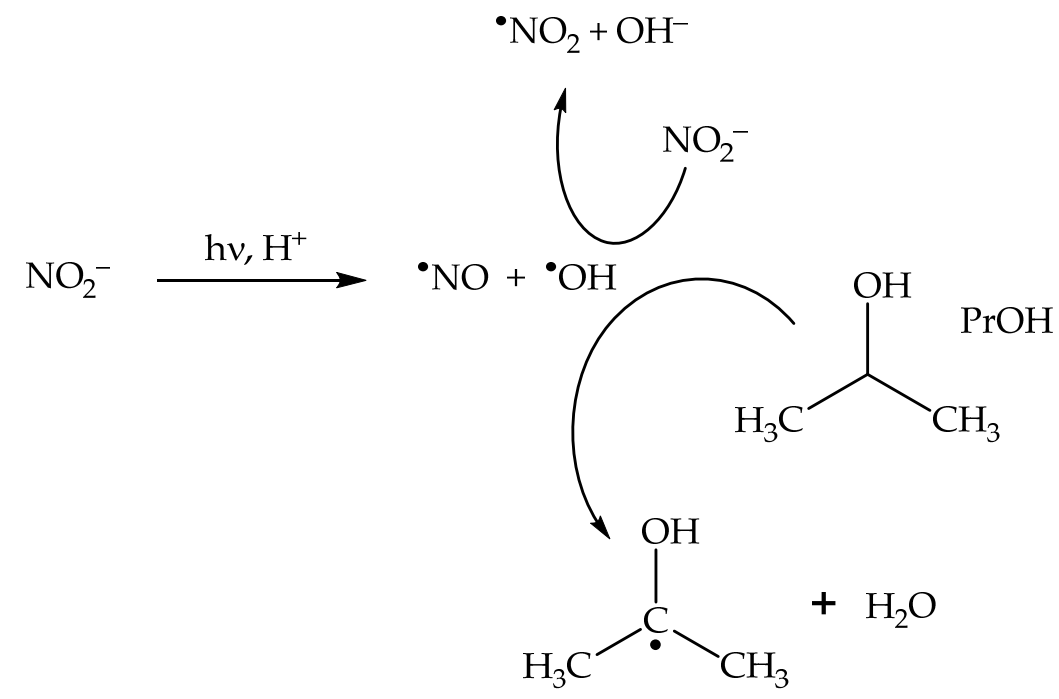

Scheme 8. Inhibition of ${ }^{\bullet} \mathrm{NO}_{2}$ formation upon nitrite photolysis by the ${ }^{\bullet} \mathrm{OH}$ scavenger 2 propanol $(\mathrm{PrOH})$.

To sum up, phenol as an electron-rich aromatic compound can undergo photonitration by virtually all the nitrating species generated by nitrate and nitrite under irradiation$\bullet \mathrm{NO}_{2}, \mathrm{HNO}_{2}, \mathrm{HOONO}$ and $\mathrm{H}_{2} \mathrm{OONO}^{+}$. However, the roles of $\bullet \mathrm{NO}_{2}$ and $\mathrm{HNO}_{2}$ strongly prevail over those of $\mathrm{HOONO}$ and $\mathrm{H}_{2} \mathrm{OONO}^{+}$, which cannot be highlighted to a significant extent in the presence of important competing processes. In contrast, nitrophenol formation has been reported in the presence of HOONO, thermally produced upon the reaction between $\mathrm{HNO}_{2}$ and $\mathrm{H}_{2} \mathrm{O}_{2}$ [54], and robust evidence confirms the ability of $\mathrm{HOONO}$ to nitrate phenolic compounds [55]. The issue with photonitration is different, because $\mathrm{HOONO}$ and $\mathrm{H}_{2} \mathrm{OONO}^{+}$are generated in quite a small amount.

It is also very interesting to highlight that both ${ }^{\bullet} \mathrm{NO}_{2}$ and $\mathrm{HNO}_{2}$ are able to oxidise phenol to the phenoxyl radical $[16,27,43]$, which is a key step in the (photo)nitration process.

\subsection{The Photonitration of Nitrophenols}

Phenol is amenable to photonitration as shown in the previous section, but this activated aromatic compound can be nitrated under a very wide variety of conditions, both thermal (which in atmospheric waters might also involve $\mathrm{N}_{2} \mathrm{O}_{5}$, produced by reaction of $\bullet \mathrm{NO}_{3}+{ }^{\bullet} \mathrm{NO}_{2}$, in addition to $\mathrm{HNO}_{2}$ ), and photochemical [56]. Therefore, secondary environmental nitrophenols might in principle arise from a plethora of nitration pathways, of which photonitration is only one of the possibilities. In contrast, it is quite difficult to account for the nitration of nitrophenols (2NP, 4NP) to 2,4-dinitrophenol (24DNP), i.e., the most phytotoxic nitrophenol compound [56,57], without invoking the photoinduced nitration pathways.

For instance, dark nitration of nitrophenols by ${ }^{\bullet} \mathrm{NO}_{2}$ or $\mathrm{HNO}_{2}$ can be excluded, because neither reactant is able to oxidise either $2 \mathrm{NP}$ or $4 \mathrm{NP}$ to the corresponding nitrophenoxyl radical [2]. In contrast, photonitration is enabled by the fact that nitrophenols absorb UV-Vis radiation, which induces their photolysis to form the corresponding nitrophenoxyl radicals as the primary reaction intermediates [58]. These radicals can then react with photogenerated ${ }^{\bullet} \mathrm{NO}_{2}$ to finally produce 24DNP (Scheme 9).

Interestingly, the formation rate of 24DNP by irradiated nitrite shows an inflection point at $\mathrm{pH} \sim 3.5$, despite the fact that nitrophenols do not react with $\mathrm{HNO}_{2}$ directly [2]. The issue is that $\mathrm{HNO}_{2}$ is a more effective photochemical and/or thermal source of ${ }^{\bullet} \mathrm{NO}_{2}$ (reactions 19-21) compared to $\mathrm{NO}_{2}{ }^{-}$, and photogenerated $\bullet \mathrm{NO}_{2}$ can then react with the nitrophenoxyl radicals produced by irradiation of nitrophenols. 


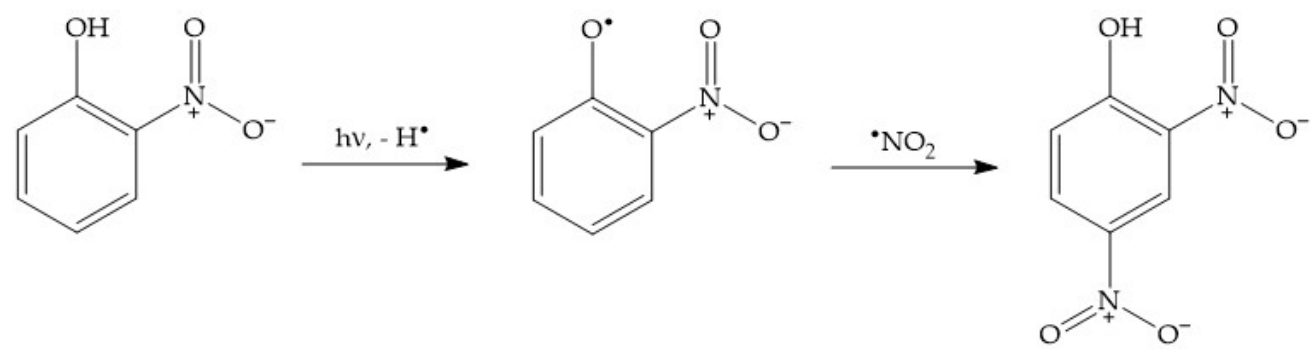

Scheme 9. Photonitration pathway of 2NP to 24DNP. Note that a similar process would involve 4NP, to also produce $24 \mathrm{DNP}$.

\subsection{Photonitration by $\mathrm{HOONO} / \mathrm{H}_{2} \mathrm{OONO}^{+}$: The Case of Naphthalene $/ \mathrm{NO}_{3}{ }^{-} / \mathrm{hv}$}

Naphthalene is a relatively electron-poor aromatic compound that, similarly to nitrophenols, cannot undergo nitration by either ${ }^{\bullet} \mathrm{NO}_{2}$ or $\mathrm{HNO}_{2}$. However, unlike nitrophenols, naphthalene does not absorb environmental UV radiation, thus, a photolysis/nitration pathway similar to that reported in Scheme 9 cannot be operational in this case. By completely excluding the main nitrating agents produced by nitrate photolysis $\left({ }^{\bullet} \mathrm{NO}_{2}, \mathrm{HNO}_{2}\right)$, naphthalene could be a good substrate for photonitration induced by the nitrating species produced in a lesser amount $\left(\mathrm{H}_{2} \mathrm{OONO}^{+}\right.$and $\left.\mathrm{HOONO}\right)$. The available experimental evidence suggests that naphthalene can actually undergo nitration by $\mathrm{H}_{2} \mathrm{OONO}^{+}$to mainly yield 1-nitronaphthalene, and by HOONO to mainly produce 2-nitronaphthalene [40]. Because the two nitronaphthalene isomers are produced to a large extent by different nitrating species, one could expect the $\mathrm{pH}$ trends of the respective formation rates to be different. Indeed, as suggested by Figure 2, the formation rate of 1-nitronaphthalene was directly proportional to $\left[\mathrm{H}^{+}\right]$, while that of 2-nitronaphthalene was dependent on $\mathrm{pH}$ to a much lesser extent in the tested acidic range [40]. For naphthalene, the involvement of $\mathrm{H}_{2} \mathrm{OONO}^{+}$and $\mathrm{HOONO}$ in photonitration could be highlighted because of the lack of reactivity with $\mathrm{HNO}_{2}$ and $\bullet \mathrm{NO}_{2}$.

Photonitration by $\mathrm{HOONO}$ in the presence of $\mathrm{NO}_{3}{ }^{-} / \mathrm{h} v$ has also been reported for benzene, which is another relatively electron-poor substrate that does not react with either $-\mathrm{NO}_{2}$ or $\mathrm{HNO}_{2}$. The formation rate of nitrobenzene did not show a significant $\mathrm{pH}$ trend in the acidic region, as expected for a process involving HOONO (see Figure 2) [59].

\subsection{Nitrosation/Oxidation by Photogenerated $\mathrm{HNO}_{2}$ : The Cases of Catechol and 1-Naphthol with $\mathrm{NO}_{3}{ }^{-} / \mathrm{hv}$}

Nitration of both catechol and 1-naphthol (1-hydroxynaphthalene) was observed upon irradiation in the presence of nitrate, with respective production of 4-nitrocatechol and of 2-nitro-1-naphthol [43]. The formation rates of both nitroaromatics under irradiation conditions showed a maximum around $\mathrm{pH} 3$. Both catechol and 1-naphthol react with $\mathrm{HNO}_{2}$ in the dark to yield the mentioned nitroderivatives, but the $\mathrm{pH}$ trend of the two nitroaromatic compounds is quite peculiar. In both cases one observes initial formation rates with an inflection point around $\mathrm{pH} 3.5$, as expected by a direct involvement of $\mathrm{HNO}_{2}$ in the nitration process (Figure 2). However, when focusing on the concentration values of the nitroderivatives reached after 30-40 min reaction time, one observes a $\mathrm{pH} 3$ maximum that is very similar to the $\mathrm{pH}$ trend observed in the photonitration process. The maximum around $\mathrm{pH} 3$, together with the fact that this phenomenon is observed only after a certain time lapse, suggests that $\mathrm{HNO}_{2}$ triggers a nitrosation/oxidation process in addition to the direct nitration (Figure 2). Coherently, nitrosoderivatives of both catechol and 1-naphthol have been detected in the presence of $\mathrm{HNO}_{2}$ in the dark [43].

Overall, the mentioned photonitration process observed in the presence of irradiated nitrate with catechol and 1-naphthol can be accounted for in the hypothesis that the nitrating agent is $\mathrm{HNO}_{2}$, operating mainly through a nitrosation/oxidation pathway [43]. Oxidation of the nitrosoderivatives is likely to be faster in the presence of nitrate under irradiation compared to $\mathrm{HNO}_{2}$ in the dark, considering that in the former conditions 
one also has the photogeneration of ${ }^{\bullet} \mathrm{OH}$, which is a very strong oxidising agent $[60,61]$. A nitrosation/oxidation process is also believed to be responsible for the considerable formation of 4-nitrophenol upon irradiation of phenol and nitrite in basic solution (optimal $\mathrm{pH}$ for this process is in the range 9-10, and nitrosation of phenol to 4-nitrosophenol is likely induced by ${ }^{\bullet} \mathrm{NO}_{2}+{ }^{\bullet} \mathrm{NO}$ instead of $\mathrm{HNO}_{2}$ ) [62].

\subsection{Proposal of a Protocol for the Study of Photonitration Pathways}

As mentioned in previous sections, photonitration is actually a very complex process that stems from the generation of a wide range of different nitrating agents, which differ in the produced amount and intrinsic reactivity. Therefore, the actual production of the nitroderivatives results from the combination of substrate activation to the nitration process, and from the availability of the nitrating agent. However, as a rule of thumb, the electronrich compounds are more likely to undergo nitration mostly by ${ }^{\bullet} \mathrm{NO}_{2}$ and $\mathrm{HNO}_{2}(\mathrm{HOONO}$ and $\mathrm{H}_{2} \mathrm{OONO}^{+}$are also reactive [54,63], but they occur in a lesser amount). In contrast, electron-poor substrates that are unreactive towards ${ }^{\circ} \mathrm{NO}_{2} / \mathrm{HNO}_{2}$ can only be nitrated by $\mathrm{HOONO} / \mathrm{H}_{2} \mathrm{OONO}{ }^{+}$. A partial exception to this rule is represented by electron-poor phenols absorbing UV-Vis radiation, such as the nitrophenols. These compounds are unreactive towards ${ }^{\circ} \mathrm{NO}_{2}$, but radiation absorption yields the corresponding phenoxyl radicals [64] that easily produce nitrophenols when reacting with ${ }^{\bullet} \mathrm{NO}_{2}$ itself.

In the case of a compound for which reactivity is still unknown, it might be very useful to proceed to the study of the photonitration pathway in a systematic way. Based on previous knowledge, which has been gathered with a range of compounds showing different reactivity towards photonitration, the following actions are foreseen:

1. In neutral solution, there is a real chance for ${ }^{\bullet} \mathrm{NO}_{2}$ to be involved in photonitration (especially with electron-rich substrates). Addition of ${ }^{\bullet} \mathrm{OH}$ scavengers such as alcohols may help supporting the possible involvement of ${ }^{\bullet} \mathrm{NO}_{2}$-indeed, photonitration by nitrate should be enhanced upon addition of the scavengers, if it involves - $\mathrm{NO}_{2}$ (solvent-cage effect, see Scheme 1 ). In contrast, ${ }^{\bullet} \mathrm{OH}$ scavengers should inhibit photonitration by nitrite $\left({ }^{\bullet} \mathrm{OH}\right.$ is needed to oxidise $\mathrm{NO}_{2}{ }^{-}$to ${ }^{\bullet} \mathrm{NO}_{2}$, see Scheme 2);

2. The effect of $\mathrm{pH}$ is key to differentiate between different reactive species, especially in the case of nitrate irradiation. Therefore, photonitration rates should be studied as a function of $\mathrm{pH}$ with irradiated nitrate, comparing the results with those reported in Figure 2. In several cases, such a comparison will give a clue as to which reactive species is mostly involved in the process;

3. If the $\mathrm{pH}$ trend of photonitration by $\mathrm{NO}_{3}^{-} / \mathrm{UV}$ suggests the possible involvement of $\mathrm{HNO}_{2}$, it is advisable to directly study the reactivity of the substrate with $\mathrm{HNO}_{2}$ in the dark $\left(\mathrm{HNO}_{2}\right.$ is produced by acidifying an $\mathrm{NO}_{2}{ }^{-}$solution). Direct nitration by $\mathrm{HNO}_{2}$ is studied by taking into account the initial formation rates of the nitroderivatives, while the nitrosation/oxidation process is highlighted by quantifying the concentration values reached by the nitroderivatives after a certain amount of time (e.g., 30 to $60 \mathrm{~min}$ reaction time in the dark). Note that the oxidation of the nitrosoderivatives might be faster with $\mathrm{NO}_{3}{ }^{-}$under irradiation than with $\mathrm{HNO}_{2}$ in the dark;

4. If, in contrast, the $\mathrm{pH}$ trend of photonitration suggests the involvement of HOONO or $\mathrm{H}_{2} \mathrm{OONO}^{+}$, one should study the dark reactivity of these species. HOONO can be produced in the dark by the reaction of $\mathrm{H}_{2} \mathrm{O}_{2}+\mathrm{HNO}_{2}$ [54]. An important issue is that the dark formation of $\mathrm{HOONO}$ involves $\mathrm{H}_{3} \mathrm{O}_{2}{ }^{+}+\mathrm{HNO}_{2}$, thus the $\mathrm{pH}$ trend of nitroderivatives formed by $\mathrm{HOONO}$ in the dark would show an inflection point at $\mathrm{pH} \sim 1.5$ [54], which is not expected to be seen in the corresponding process taking place under irradiation. In contrast, the involvement of $\mathrm{H}_{2} \mathrm{OONO}^{+}$in dark nitration would still produce nitroderivative formation rates that are $\propto\left[\mathrm{H}^{+}\right]$.

By considering together the results of scavenger addition, $\mathrm{pH}$ trend and dark control experiments, one should gather enough information to understand which photonitration processes are prevailing for a given substrate under different conditions. 


\subsection{Possible Occurrence of Photonitration in Natural Waters}

Evidence of the possible occurrence of photonitration processes in the natural environment has been obtained in the case of natural surface waters, although biological nitration pathways cannot be ruled out. In particular, it appears that the environmental conditions of the Rhône delta lagoons (shallow and sunlit waters, elevated concentrations of nitrate and nitrite) are particularly favourable to the transformation of phenolic compounds, arising from the environmental dissipation of phenoxyacid herbicides, into the corresponding nitroderivatives [31,65-69]:

- 2,4-Dichlorophenoxyacetic acid $\rightarrow$ 2,4-dichlorophenol $\rightarrow$ 2,4-dichloro-6-nitrophenol

- $\quad \mathrm{MCPA} \rightarrow$ 4-chloro-2-methylphenol $\rightarrow$ 4-chloro-2-methyl-6-nitrophenol

- $\quad$ Dichlorprop $\rightarrow$ 4-chlorophenol $\rightarrow$ 2-nitro-4-chlorophenol where MCPA $=4$-chloro-2methylphenoxyacetic acid, and dichlorprop $=2$-(2,4-dichlorophenoxy) propanoic acid.

It should be remarked that natural waters are indeed much more complex compared to simplified laboratory systems, thus interaction between different components is highly likely. For instance, nitrate and nitrite occur together in the Rhône-delta lagoon water, and the processes they may trigger differ from the mere sum of the separate photoreactions. In particular, the oxidation of $\mathrm{NO}_{2}{ }^{-}$to ${ }^{\bullet} \mathrm{NO}_{2}$ can be carried out by the ${ }^{\bullet} \mathrm{OH}$ radicals produced by both nitrate and nitrite photolysis [70]. Moreover, surface waters contain additional components that can affect the process. For example, iron oxides such as hematite $\left(\alpha-\mathrm{Fe}_{2} \mathrm{O}_{3}\right)$ have been shown to remarkably favour the photonitration both of phenol [71] and of the chlorinated phenols that undergo nitration in the Rhône delta lagoons [31,67]. Further, the oxidation of $\mathrm{NO}_{2}{ }^{-}$to ${ }^{\bullet} \mathrm{NO}_{2}$ by ${ }^{\bullet} \mathrm{OH}$ can be inhibited by a number of ${ }^{\bullet} \mathrm{OH}$ scavengers that occur in natural waters, such as natural organic matter and inorganic carbon. That said, Scheme 10 shows a summary of the possible reaction pathways that might account for the photonitration of 2,4-dichlorophenol into 2,4-dichloro-6-nitrophenol in lagoon waters. Similar reaction pathways are likely to be operational for the other compounds.

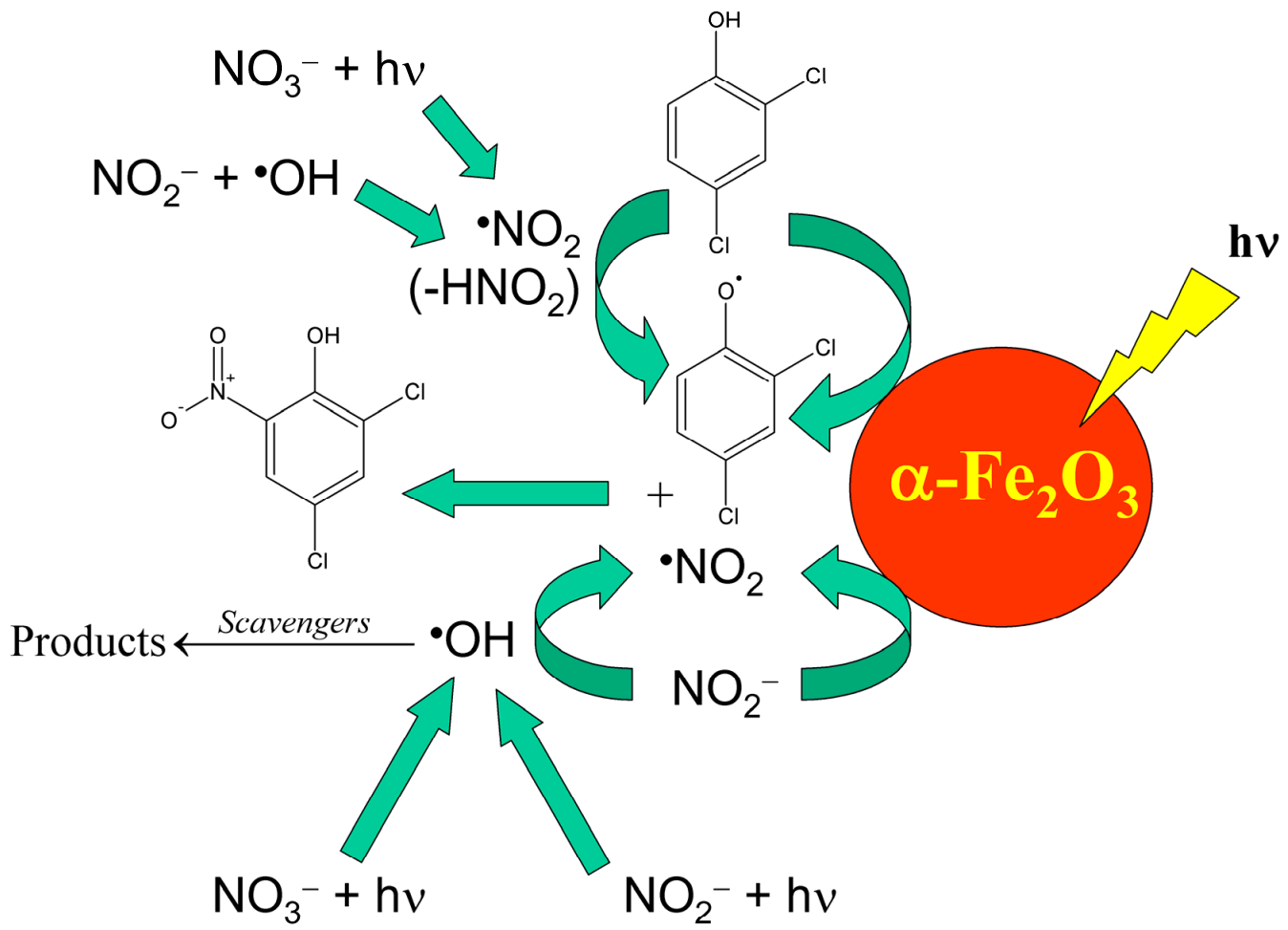

Scheme 10. Environmental reaction pathways that could account for the photochemical nitration of 2,4-dichlorophenol into 2,4-dichloro-6-nitrophenol. 


\section{Conclusions}

The irradiation of nitrate and nitrite ions under environmentally significant UV radiation or sunlight yields a number of nitrating agents $\left({ }^{\bullet} \mathrm{NO}_{2}, \mathrm{HNO}_{2}, \mathrm{HOONO}, \mathrm{H}_{2} \mathrm{OONO}{ }^{+}\right)$, which account for the formation of nitroderivatives of a large number of aromatic compounds. This so-called photonitration process can proceed differently depending on the aromatic substrate under consideration, its reactivity towards the different nitrating agents (which depends on its electron-rich or electron-poor nature) and, in some cases, the substrate's ability to absorb radiation and undergo photolysis as a consequence. Photonitration is usually favoured at acidic $\mathrm{pH}$, albeit with different trends, depending on the involvement of $\mathrm{HNO}_{2}, \mathrm{HOONO}$ and / or $\mathrm{H}_{2} \mathrm{OONO}^{+}$in the process. Indeed, the study of the $\mathrm{pH}$ trend of nitroderivative formation is one of the most effective ways to understand the details of the process. Additionally, ${ }^{\bullet} \mathrm{OH}$ scavengers such as alcohols can enhance the formation of the nitroderivatives in the presence of irradiated nitrate, and inhibit it with irradiated nitrite. The reason is, on the one side, the fact that ${ }^{\bullet} \mathrm{OH}$ scavengers at large enough concentrations can interfere with the geminate recombination processes of the radical fragments $\left(\mathrm{O}^{\bullet-}\right.$ and ${ }^{\bullet} \mathrm{NO}_{2}$ ) that occur in the solvent cage soon after nitrate photolysis, thereby enhancing ${ }^{\bullet} \mathrm{NO}_{2}$ formation. In the case of nitrite, ${ }^{\bullet} \mathrm{OH}$ is essential for the oxidation of $\mathrm{NO}_{2}{ }^{-}$to ${ }^{\bullet} \mathrm{NO}_{2}$, which is understandably inhibited by scavenger addition.

There is evidence that photonitration may be operational in the shallow lagoon water of the Rhône river delta (S. France), involving chlorophenols that are produced as transformation intermediates of chlorophenoxyacid herbicides, and that are transformed into the corresponding nitroderivatives. In such a system, the different photoactive components (nitrate, nitrite, Fe oxide colloids) may interact among themselves, with the substrates, with the nitrating agents and with the natural ${ }^{\bullet} \mathrm{OH}$ scavengers (organic matter, inorganic carbon), thereby providing a process that is unavoidably more complex than those occurring in laboratory solutions under irradiation.

The occurrence of nitrate and nitrite in water and wastewater opens up the additional possibility for nitroaromatic compounds to be formed also in the framework of photochemical processes for water treatment, where radiation is often provided by UV lamps and where the aromatic substrates may occur either as contaminants, or as components of the natural organic matter. In some cases, nitrite may even occur together with strong oxidising agents intended for pollutant degradation, yielding nitroderivatives upon oxidation to $\bullet \mathrm{NO}_{2}$ [72-75].

Finally, if the photonitration process was also operational in atmospheric aerosols, it might contribute to the formation of a range of compounds having phytotoxic and mutagenic properties, and would affect the aerosol's ability to absorb sunlight. The latter phenomenon would influence the earth's radiation budget, with potential climatic implications.

Author Contributions: G.M. wrote the first draft of the manuscript. D.V. conceived the work and finalised the manuscript. All authors have read and agreed to the published version of the manuscript.

Funding: This work received no external funding.

Institutional Review Board Statement: Not applicable.

Informed Consent Statement: Not applicable.

Data Availability Statement: Data availability is not applicable to this review paper.

Conflicts of Interest: The authors declare no conflict of interest.

Sample Availability: Sample availability is not applicable to this review paper.

\section{References}

1. Dzengel, J.; Theurich, J.; Bahnemann, D.W. Formation of nitroaromatic compounds in advanced oxidation processes: Photolysis versus photocatalysis. Environ. Sci. Technol. 1999, 33, 294-300. [CrossRef]

2. Vione, D.; Maurino, V.; Minero, C.; Pelizzetti, E. Aqueous atmospheric chemistry: Formation of 2,4-dinitrophenol upon nitration of 2-nitrophenol and 4-nitrophenol in solution. Environ. Sci. Technol. 2005, 39, 7921-7931. [CrossRef] 
3. Suzuki, J.; Okazaki, H.; Sato, T.; Suzuki, S. Formation of mutagens by photochemical reaction of biphenyl in nitrate aqueous solution. Chemosphere 1982, 11, 437-444. [CrossRef]

4. Suzuki, J.; Ueki, T.; Shimizu, S.; Uesugi, K.; Suzuki, S. Formation of mutagens by photolysis of amino acids in neutral aqueous solution containing nitrite or nitrate ion. Chemosphere 1985, 14, 493-500. [CrossRef]

5. Scholes, R.C.; Prasse, C.; Sedlak, D.L. The role of reactive nitrogen species in sensitized photolysis of wastewater-derived Trace organic contaminants. Environ. Sci. Technol. 2019, 53, 6483-6491. [CrossRef]

6. Machado, F.; Boule, P. Photonitration and photonitrosation of phenolic derivatives induced in aqueous solution by excitation of nitrite and nitrate ions. J. Photochem. Photobiol. A Chem. 1995, 86, 73-80. [CrossRef]

7. Natangelo, M.; Mangiapan, S.; Bagnati, R.; Benfenati, E.; Fanelli, R. Increased concentrations of nitrophenols in leaves from a damaged forestal site. Chemosphere 1999, 38, 1495-1503. [CrossRef]

8. Sugiyama, H.; Watanabe, T.; Hirayama, T. Nitration of pyrene in metallic oxides as soil components in the presence of indoor air, nitrogen dioxide gas, nitrite ion, or nitrate ion under xenon irradiation. J. Health Sci. 2001, 47, 28-35. [CrossRef]

9. Guidi, G.; Librando, V.; Minniti, Z.; Bolzacchini, E.; Perrini, G.; Bracchitta, G.; Alparone, A.; Catalfo, A. The PAH and nitro-PAH concentration profiles in size-segregated urban particulate matter and soil in traffic-related sites in Catania, Italy. Polycycl. Aromat. Compd. 2012, 32, 439-456. [CrossRef]

10. Rubio, M.A.; Lissi, E.; Herrera, N.; Pérez, V.; Fuentes, N. Phenol and nitrophenols in the air and dew waters of Santiago de Chile. Chemosphere 2012, 86, 1035-1039. [CrossRef] [PubMed]

11. Kitanovski, Z.; Čusak, A.; Grgić, I.; Claeys, M. Chemical characterization of the main products formed through aqueous-phase photonitration of guaiacol. Atmos. Meas. Tech. 2014, 7, 2457-2470. [CrossRef]

12. Kroflič, A.; Grilc, M.; Grgić, I. Unraveling pathways of guaiacol nitration in atmospheric waters: Nitrite, a source of reactive nitronium ion in the atmosphere. Environ. Sci. Technol. 2015, 49, 9150-9158. [CrossRef] [PubMed]

13. Vidović, K.; Jurković, D.L.; Šala, M.; Kroflič, A.; Grgić, I. Nighttime aqueous-phase formation of nitrocatechols in the atmospheric condensed phase. Environ. Sci. Technol. 2018, 52, 9722-9730. [CrossRef]

14. Kroflič, A.; Huš, M.; Grilc, M.; Grgić, I. Underappreciated and complex role of nitrous acid in aromatic nitration under mild environmental conditions: The case of activated methoxyphenols. Environ. Sci. Technol. 2018, 52, 13756-13765. [CrossRef] [PubMed]

15. Vidović, K.; Kroflič, A.; Šala, M.; Grgić, I. Aqueous-phase brown carbon formation from aromatic precursors under sunlight conditions. Atmosphere 2020, 11, 131. [CrossRef]

16. Pang, H.; Zhang, Q.; Lu, X.; Li, K.; Chen, H.; Chen, J.; Yang, X.; Ma, Y.; Ma, J.; Huang, C. Nitrite-mediated photooxidation of vanillin in atmospheric aqueous phase. Environ. Sci. Technol. 2019, 53, 14253-14263. [CrossRef]

17. Huang, Y.; Kong, M.; Westerman, D.C.; Xu, E.G.; Coffin, S.; Cochran, K.H.; Liu, Y.; Richardson, S.; Schlenk, D.; Dionysiou, D. Effects of $\mathrm{HCO}_{3}{ }^{-}$on degradation of toxic contaminants of emerging concern by $\mathrm{UV} / \mathrm{NO}_{3}{ }^{-}$. Environ. Sci. Technol. 2018, 52, 12697-12707. [CrossRef] [PubMed]

18. Wu, Z.; Chen, C.; Zhu, B.; Huang, C.; An, T.; Meng, F.; Fang, J. Reactive nitrogen species are also involved in the transformation of micropollutants by the UV/monochloramine process. Environ. Sci. Technol. 2019, 53, 11142-11152. [CrossRef]

19. Xu, L.; Sun, Y.; Gan, L.; Han, J.; Wang, P.; Yu, L.; Mei, X.; Li, W.; Lyu, B.; Pei, C.; et al. Utilization of photochemical circulation between $\mathrm{NO}_{3}{ }^{-}$and $\mathrm{NO}_{2}{ }^{-}$in water to degrade photoinert dimethyl phthalate: Influence of organic media and mechanism study. Appl. Catal. B Environ. 2019, 259, 117958. [CrossRef]

20. Zhou, S.; Li, L.; Wu, Y.; Zhu, S.; Zhu, N.; Bu, L.; Dionysiou, D. UV365 induced elimination of contaminants of emerging concern in the presence of residual nitrite: Roles of reactive nitrogen species. Water Res. 2020, 178, 115829. [CrossRef]

21. Chen, C.; Wu, Z.; Zheng, S.; Wang, L.; Niu, X.; Fang, J. Comparative study for interactions of sulfate radical and hydroxyl radical with phenol in the presence of nitrite. Environ. Sci. Technol. 2020, 54, 8455-8463. [CrossRef]

22. Mack, J.; Bolton, J. Photochemistry of nitrite and nitrate in aqueous solution: A review. J. Photochem. Photobiol. A Chem. 1999, 128, 1-13. [CrossRef]

23. Vione, D.; Sur, B.; Dutta, B.K.; Maurino, V.; Minero, C. On the effect of 2-propanol on phenol photonitration upon nitrate photolysis. J. Photochem. Photobiol. A Chem. 2011, 224, 68-70. [CrossRef]

24. Carena, L.; Vione, D. Photochemical reaction of peroxynitrite and carbon dioxide could account for up to $15 \%$ of carbonate radicals generation in surface waters. Environ. Chem. Lett. 2016, 14, 183-187. [CrossRef]

25. Ohta, T.; Suzuki, J.; Iwano, Y.; Suzuki, S. Photochemical nitrosation of dimethylamine in aqueous solution containing nitrite. Chemosphere 1982, 11, 797-801. [CrossRef]

26. Vione, D.; Minero, C.; Housari, F.; Chirón, S. Photoinduced transformation processes of 2,4-dichlorophenol and 2,6-dichlorophenol on nitrate irradiation. Chemosphere 2007, 69, 1548-1554. [CrossRef] [PubMed]

27. Bedini, A.; Maurino, V.; Minero, C.; Vione, D. Theoretical and experimental evidence of the photonitration pathway of phenol and 4-chlorophenol: A mechanistic study of environmental significance. Photochem. Photobiol. Sci. 2012, 11, 418-424. [CrossRef] [PubMed]

28. Shankar, M.; Nélieu, S.; Kerhoas, L.; Einhorn, J. Photo-induced degradation of diuron in aqueous solution by nitrites and nitrates: Kinetics and pathways. Chemosphere 2007, 66, 767-774. [CrossRef]

29. Ge, J.; Huang, D.; Han, Z.; Wang, X.; Wang, Z. Photochemical behavior of benzophenone sunscreens induced by nitrate in aquatic environments. Water Res. 2019, 153, 178-186. [CrossRef] 
30. Palma, D.; Arbid, Y.; Sleiman, M.; Sainte-Claire, P.D.; Richard, C. New route to toxic nitro and nitroso products upon irradiation of micropollutants mixtures containing imidacloprid: Role of $\mathrm{NO}_{\mathrm{x}}$ and effect of natural organic matter. Environ. Sci. Technol. 2020, 54, 3325-3333. [CrossRef]

31. Chirón, S.; Minero, C.; Vione, D. Occurrence of 2,4-dichlorophenol and of 2,4-dichloro-6-nitrophenol in the Rhône River Delta (Southern France). Environ. Sci. Technol. 2007, 41, 3127-3133. [CrossRef] [PubMed]

32. Chen, L.; Kong, L.; Tong, S.; Yang, K.; Jin, S.; Wang, C.; Wang, L. Aqueous phase oxidation of bisulfite influenced by nitrate photolysis. Atmos. Chem. Phys. 2020, 1-40. [CrossRef]

33. Bianco, A.; Passananti, M.; Brigante, M.; Mailhot, G. Photochemistry of the cloud aqueous phase: A review. Molecules 2020, 25, 423. [CrossRef] [PubMed]

34. Mariotti, M.; Rogowska-Wrzesińska, A.; Hägglund, P.; Davies, M.J. Cross-linking and modification of fibronectin by peroxynitrous acid: Mapping and quantification of damage provides a new model for domain interactions. J. Biol. Chem. 2021, 296, 100360. [CrossRef] [PubMed]

35. Benedict, K.; McFall, A.S.; Anastasio, C. Quantum yield of nitrite from the photolysis of aqueous nitrate above $300 \mathrm{~nm}$. Environ. Sci. Technol. 2017, 51, 4387-4395. [CrossRef]

36. Yang, W.; Han, C.; Yang, H.; Xue, X. Significant HONO formation by the photolysis of nitrates in the presence of humic acids. Environ. Pollut. 2018, 243, 679-686. [CrossRef]

37. Maiti, B.K.; Maia, L.; Moura, I.; Moura, J. Ni ${ }^{\mathrm{II}}$-ATCUN-catalyzed tyrosine nitration in the presence of nitrite and sulfite. Chem. Eur. J. 2019, 25, 4309-4314. [CrossRef]

38. De Laurentiis, E.; Minella, M.; Berto, S.; Maurino, V.; Minero, C.; Vione, D. The fate of nitrogen upon nitrite irradiation: Formation of dissolved vs. gas-phase species. J. Photochem. Photobiol. A Chem. 2015, 307, 30-34. [CrossRef]

39. Fu, X.; Wang, T.; Zhang, L.; Li, Q.; Wang, Z.; Xia, M.; Yun, H.; Wang, W.; Yu, C.; Yue, D.; et al. The significant contribution of HONO to secondary pollutants during a severe winter pollution event in southern China. Atmos. Chem. Phys. 2019, 19, 1-14. [CrossRef]

40. Vione, D.; Maurino, V.; Minero, C.; Pelizzetti, E. Nitration and photonitration of naphthalene in aqueous systems. Environ. Sci. Technol. 2005, 39, 1101-1110. [CrossRef]

41. Degendorfer, G.; Chuang, C.; Mariotti, M.; Hammer, A.; Hoefler, G.; Hägglund, P.; Malle, E.; Wise, S.G.; Davies, M. Exposure of tropoelastin to peroxynitrous acid gives high yields of nitrated tyrosine residues, di-tyrosine cross-links and altered protein structure and function. Free Rad. Biol. Med. 2018, 115, 219-231. [CrossRef] [PubMed]

42. Campolo, N.; Issoglio, F.; Estrin, D.; Bartesaghi, S.; Radi, R. 3-Nitrotyrosine and related derivatives in proteins: Precursors, radical intermediates and impact in function. Essays Biochem. 2020, 64, 111-133. [CrossRef] [PubMed]

43. Minero, C.; Bono, F.; Rubertelli, F.; Pavino, D.; Maurino, V.; Pelizzetti, E.; Vione, D. On the effect of pH in aromatic photonitration upon nitrate photolysis. Chemosphere 2007, 66, 650-656. [CrossRef] [PubMed]

44. Vione, D.; De Laurentiis, E.; Berto, S.; Minero, C.; Hatipoglu, A.; Çınar, Z. Modeling the photochemical transformation of nitrobenzene under conditions relevant to sunlit surface waters: Reaction pathways and formation of intermediates. Chemosphere 2016, 145, 277-283. [CrossRef]

45. Mekic, M.; Liu, J.; Zhou, W.; Loisel, G.; Cai, J.; He, T.; Jiang, B.; Yu, Z.; Lazarou, Y.; Li, X.; et al. Formation of highly oxygenated multifunctional compounds from cross-reactions of carbonyl compounds in the atmospheric aqueous phase. Atmos. Environ. 2019, 219, 117046. [CrossRef]

46. Hayyan, M.; Hashim, M.A.; Al Nashef, I. Superoxide ion: Generation and chemical implications. Chem. Rev. 2016, 116, 3029-3085. [CrossRef]

47. Wang, F. Reactivity of the Solvated Electron, the Hydroxyl Radical and Its Precursor in Deuterated Water Studied by Picosecond Pulse Radiolysis. Ph.D. Thesis, Université Paris Saclay, Paris, France, 2018; p. 179.

48. Nayebzadeh, M.; Vahedpour, M. A Review on reactions of polycyclic aromatic hydrocarbons with the most abundant atmospheric chemical fragments: Theoretical and experimental data. Prog. React. Kinet. Mech. 2017, 42, 201-220. [CrossRef]

49. Mao, X.; Wang, S.; Huang, Y.; Zhou, T. A theoretical investigation of gas phase OH-initiated acenaphthylene degradation reaction. Comput. Chem. 2017, 5, 22-37. [CrossRef]

50. Rubio, M.A.; Lissi, E.; Olivera, N.; Reyes, J.; López-Alarcón, C. Reactions of p-substituted phenols with nitrous acid in aqueous solution. Int. J. Chem. Kinet. 2014, 46, 143-150. [CrossRef]

51. Takahama, U.; Hirota, S. Possible reactions of dietary phenolic compounds with salivary nitrite and thiocyanate in the stomach. Antioxidants 2017, 6, 53. [CrossRef] [PubMed]

52. Vione, D.; Maurino, V.; Minero, C.; Pelizzetti, E. Phenol photonitration. Ann. Chim. 2002, 92, 919-929.

53. Vione, D.; Maurino, V.; Minero, C.; Pelizzetti, E. Phenol photonitration upon UV irradiation of nitrite in aqueous solution II: Effects of $\mathrm{pH}$ and $\mathrm{TiO}_{2}$. Chemosphere 2001, 45, 903-910. [CrossRef]

54. Vione, D.; Maurino, V.; Minero, C.; Borghesi, D.; Lucchiari, M.; Pelizzetti, E. New processes in the environmental chemistry of nitrite. 2. The role of hydrogen peroxide. Environ. Sci. Technol. 2003, 37, 4635-4641. [CrossRef]

55. Bartesaghi, S.; Radi, R. Fundamentals on the biochemistry of peroxynitrite and protein tyrosine nitration. Redox Biol. 2018, 14, 618-625. [CrossRef]

56. Harrison, M.; Barra, S.; Borghesi, D.; Vione, D.; Arsene, C.; Olariu, R. Nitrated phenols in the atmosphere: A review. Atmos. Environ. 2005, 39, 231-248. [CrossRef] 
57. Daviere, A.; Sotomski, M.; Audibert, A.; Carol, P.; Hubert, S.; Lebreton, S.; Louvet-Vallée, S.; Pédron, J.; Puyaubert, J.; Kraepiel, Y.; et al. Synergistic toxicity between glyphosate and 2,4-dinitrophenol on budding yeast is not due to $\mathrm{H}_{2} \mathrm{O}_{2}$-mediated oxidative stress. Matters 2019. [CrossRef]

58. Barsotti, F.; Bartels-Rausch, T.; De Laurentiis, E.; Ammann, M.; Brigante, M.; Mailhot, G.; Maurino, V.; Minero, C.; Vione, D. Photochemical formation of nitrite and nitrous acid (HONO) upon irradiation of nitrophenols in aqueous solution and in viscous secondary organic aerosol proxy. Environ. Sci. Technol. 2017, 51, 7486-7495. [CrossRef] [PubMed]

59. Vione, D.; Maurino, V.; Minero, C.; Lucchiari, M.; Pelizzetti, E. Nitration and hydroxylation of benzene in the presence of nitrite/nitrous acid in aqueous solution. Chemosphere 2004, 56, 1049-1059. [CrossRef]

60. Gligorovski, S.; Strekowski, R.; Barbati, S.; Vione, D. Environmental implications of hydroxyl radicals $\left({ }^{\bullet} \mathrm{OH}\right)$. Chem. Rev. 2015, 115, 13051-13092. [CrossRef]

61. Duan, L.; Zhang, T.; Song, W.; Jiang, C.; Hou, Y.; Zhao, W.; Chen, W.; Alvarez, P. Photolysis of graphene oxide in the presence of nitrate: Implications for graphene oxide integrity in water and wastewater treatment. Environ. Sci. Nano 2019, 6, 136-145. [CrossRef]

62. Vione, D.; Maurino, V.; Pelizzetti, E.; Minero, C. Phenol photonitration and photonitrosation upon nitrite photolysis in basic solution. Int. J. Environ. Anal. Chem. 2004, 84, 493-504. [CrossRef]

63. Lorentzen, L.; Chuang, C.; Rogowska-Wrzesińska, A.; Davies, M. Identification and quantification of sites of nitration and oxidation in the key matrix protein laminin and the structural consequences of these modifications. Redox Biol. 2019, 24, 101226. [CrossRef]

64. Taraborrelli, D.; Cabrera-Perez, D.; Bacer, S.; Gromov, S.; Lelieveld, J.; Sander, R.; Pozzer, A. Influence of aromatics on tropospheric gas-phase composition. Atmos. Chem. Phys. 2020, 2615-2636. [CrossRef]

65. Xia, Z.; Zhang, L.; Zhao, Y.; Yan, X.; Li, S.; Gu, T.; Jiang, J. Biodegradation of the herbicide 2,4-dichlorophenoxyacetic acid by a new isolated strain of Achromobacter sp. LZ35. Curr. Microbiol. 2016, 74, 193-202. [CrossRef] [PubMed]

66. Nowak, K.; Miltner, A.; Poll, C.; Kandeler, E.; Streck, T.; Pagel, H. Plant litter enhances degradation of the herbicide MCPA and increases formation of biogenic non-extractable residues in soil. Environ. Int. 2020, 142, 105867. [CrossRef] [PubMed]

67. Chirón, S.; Comoretto, L.; Rinaldi, E.; Maurino, V.; Minero, C.; Vione, D. Pesticide by-products in the Rhône delta (Southern France). The case of 4-chloro-2-methylphenol and of its nitroderivative. Chemosphere 2009, 74, 599-604. [CrossRef] [PubMed]

68. Muszyński, P.; Brodowska, M.; Paszko, T. Occurrence and transformation of phenoxy acids in aquatic environment and photochemical methods of their removal: A review. Environ. Sci. Pollut. Res. 2019, 27, 1276-1293. [CrossRef]

69. Maddigapu, P.R.; Vione, D.; Ravizzoli, B.; Minero, C.; Maurino, V.; Comoretto, L.; Chirón, S. Laboratory and field evidence of the photonitration of 4-chlorophenol to 2-nitro-4-chlorophenol and of the associated bicarbonate effect. Environ. Sci. Pollut. Res. 2010, 17, 1063-1069. [CrossRef] [PubMed]

70. Xu, H.; Li, Y.; Liu, J.; Du, H.; Du, Y.; Su, Y.; Jiang, H. Photogeneration and steady-state concentration of hydroxyl radical in river and lake waters along middle-lower Yangtze region, China. Water Res. 2020, 176, 115774. [CrossRef]

71. Vione, D.; Maurino, V.; Minero, C.; Pelizzetti, E. New processes in the environmental chemistry of nitrite: Nitration of phenol upon nitrite photoinduced oxidation. Environ. Sci. Technol. 2002, 36, 669-676. [CrossRef]

72. Guan, C.; Jiang, J.; Shen, Y.; Pang, S.; Luo, C.; Zhao, X. Carbon materials inhibit formation of nitrated aromatic products in treatment of phenolic compounds by thermal activation of peroxydisulfate (PDS) in the presence of nitrite. Environ. Sci. Technol. 2019, 53, 9054-9062. [CrossRef] [PubMed]

73. Ji, Y.; Wang, L.; Jiang, M.; Lu, J.; Ferronato, C.; Chovelon, J. The role of nitrite in sulfate radical-based degradation of phenolic compounds: An unexpected nitration process relevant to groundwater remediation by in-situ chemical oxidation (ISCO). Water Res. 2017, 123, 249-257. [CrossRef]

74. Yang, P.; Ji, Y.; Lu, J.; Huang, Q. Formation of nitrophenolic byproducts during heat-activated peroxydisulfate oxidation in the presence of natural organic matter and nitrite. Environ. Sci. Technol. 2019, 53, 4255-4264. [CrossRef] [PubMed]

75. Zhao, X.; Zhang, T.; Lu, J.; Zhou, L.; Chovelon, J.; Ji, Y. Formation of chloronitrophenols upon sulfate radical-based oxidation of 2-chlorophenol in the presence of nitrite. Environ. Pollut. 2020, 261, 114242. [CrossRef] [PubMed] 